\title{
Karakteristik Enzim Digesti, Protease dan Amilase, Ikan Gurami (Osphronemus gouramy Lac.) pada Fase Pertumbuhan
}

\author{
Untung Susilo, Edy Yuwono, Farida Nur Rachmawati, Slamet Priyanto dan Hana \\ Lab. Fisiologi Hewan Fakultas Biologi Unsoed, Purwokerto \\ e-mail : susilo.utg@gmail.com
}

\begin{abstract}
Abstrak
Suatu penelitian untuk mengetahui karakteristik enzim digesti, protease dan amilase pada ikan gurami, Osphronemus gouramy Lac., telah dilakukan dengan metode survey. Jumlah ikan yang digunakan untuk penelitian sebanyak 25 ekor yang dikelompokan menjadi tiga kelompok ukuran13,29, 35,86 dan 91,86 g/ekor. Hasil penelitian menunjukkan bahwa aktivitas protease digesti ikan gurami berbeda secara signifikan pada segmen usus dan $\mathrm{pH}$ buffer yang berbeda $(P<.05)$. Aktivitas amilase digesti tidak berbeda secara signifikan diantara segmen usus yang diuji $(P>.05)$, namun berbeda secara signifikan diantara ukuran ikan yang berbeda $(P<.05)$, dan aktivitas amilase tertinggi dijumpai pada ikan dengan ukuran terkecil. Kesimpulan yang dapat diambil adalah bahwa aktivitas protease dan amilase dijumpai sepanjang saluran digestinya baik pada ikan yang berukuran kecil maupun besar. Aktivitas protease umumnya tinggi pada suasana asam dan netral pada usus depan dan tengah. Aktivitas protease ikan yang berukuran besar lebih rendah dari pada ikan yang berukuran lebih kecil. Aktivitas amilase tidak terdapat perbedaan diantara segmen usus yang diuji, namun aktivitas amilase tertinggi dijumpai pada ikan dengan berat rata-rata $13,29 \mathrm{~g} / \mathrm{ekor}$

Kata kunci : amilase, gouramy, pertumbuhan. protease
\end{abstract}

\begin{abstract}
A study to determine the characteristics of digestion enzymes, protease and amylase in gourami, Osphronemus gouramy Lac., has been conducted by survey method. The number of fish that are used for research as many as 25 animals were grouped into three groups $13,29,35.86$ and $91.86 \mathrm{~g}$. The results showed that the activity of digestive protease was significantly different at $\mathrm{pH}$ buffer intestinal segments and different $(P<.05)$. The activity of amylase digestive did not differ significantly between intestinal segments tested $(P>.05)$, but differed significantly among fish of different sizes $(P<.05)$, and the highest amylase activity found in fish with the smallest size. The conclusion that can be drawn is that the protease and amylase activity were found along its gut of small or large fish. Protease activity was generally high in acidic and neutral at the front and middle intestine. Protease activity of large-sized fish was lower than the smaller fish. Amylase activity there was no difference between intestinal segments, but the highest amylase activity found in fish with an average weight of $13.29 \mathrm{~g}$.
\end{abstract}

Key words : amylase,gouramy, growth, protease

\section{Pendahuluan}

Ikan gurami, Osphronemus gouramy Lac., telah lama dibudidayakan di Indonesia, termasuk di wilayah Banyumas. Ikan gurami ini juga termasuk ikan primadona di wilayah Banyumas. Namun, ikan gurami ini dikenal ikan yang pertumbuhannya lambat, sebab untuk mencapai ukuran konsumsi perlu waktu pemeliharaan yang cukup lama. Selain pertumbuhan yang lambat, kendala yang juga sering dijumpai pada budidaya ikan gurami adalah masalah pakan, baik kualitas maupun kuantitas. Kebutuhan jenis pakan yang tepat merupakan kendala utama dalam budidaya ikan gurami, sebab selama ini budidaya ikan gurami pengadaan pakannya masih mengacu pada hasil studi nutrisi spesies ikan lain yang memiliki kebiasaan makan yang hampir sama. Kondisi demikian diduga menjadi salah satu faktor penyebab sulitnya ikan gurami mencapai pertumbuhan yang optimal.

Beberapa penelitian telah dilakukan untuk mencari pemecahan permasalahan pertumbuhan ikan gurami, diantaranya dengan melakukan evaluasi pemanfaatan bahan baku lokal untuk memenuhi kebutuhan nutrisi ikan (Susilo et al., 2000), evaluasi pengggunan kedelai dan suplementasi minyak ikan lemuru serta efeknya terhadap pertumbuhan, komposisi tubuh dan retensi energy (Soedibya et al., 2001; Soedibya et al, 2002), level pemberian pakan dan efeknya pada beberapa 
parameter pertumbuhan (Susilo et al, 2003) dan kondisi fisiologis pada pertumbuhan kompensatori yang diinduksi dengan pembatasan pakan kadar protein dan efeknya terhadap pertumbuhan ikan gurami (Yuwono et al, 2008 \& 2009; Hariyadi et al, 2010). Namun, studi terdahulu yang melakukan pendekatan pada kebutuhan kualitas dan efisiensi pakan kurang fokus pada pemecahan permasalahan, sebab keterkaitan antara pertumbuhan, kebutuhan pakan dan kemampuan memanfaatkan nutrisi pada ikan gurami juga belum terungkap.

Kemampuan memanfaatkan nutrisi yang dikonsumsi oleh ikan baik untuk ikan karnivora, omnivora maupun herbivora sangat tergantung pada kapasitas fisiologi dan biokimia sistem digesti untuk melakukan proses pencernaan dan transport nutrisi yang dikonsumsinya. Kapasitas fisiologi dan biokimia tersebut diantaranya adalah kapasitas enzim digesti, yang karakteristiknya akan berbeda diantara ikan sesuai dengan keragaman struktur sistem digesti dan sumber nutrisi yang dikonsumsinya. Oleh karena itu, kapasitas atau aktivitas enzim digesti ikan menjadi penting untuk dikaji, sebab akan menjadi dasar untuk penentuan kualitas dan strategi pemberian pakan agar tercapai kesepadanan antara nutrisi yang diberikan dengan kesiapan sistem digesti. Kesepadanan ini diharapkan akan meningkatkan efisiensi pemanfaatan nutrisi yang dikonsumsi oleh ikan gurami.

Studi terdahulu tentang aktivitas enzim digesti telah dilakukan baik pada spesies ikan tropika maupun subtropika, diantaranya pada ikan nila, Oreochormis niloticus L., (Tengjaroenkul et al., 2000; Chan et al., 2008; Klahan et al., 2009), sidat sub-tropika, Anguilla anguilla (Hidalgo et al., 1999). ikan sturgeon, Acipenser naccarii dan rainbow trout, Oncorhynchus mykiss (Furne at al., 2005), ikan snakehead, Parachanna obcura (Odedeyi, 2007), dan ikan brek, Puntius orphoides C.V. (Susilo et al., 2010), yang memperlihatkan perbedaan karakteristik enzim digesti diantara spesies ikan yang telah diteliti. Namun, belum banyak informasi yang berkaitan dengan aktivitas enzim digesti pada ikan gurami fase pertumbuhan. Informasi aktivitas enzim digesti ini sangat diperlukan untuk memahami fisiologi digesti ikan gurami serta untuk menopang penetapan kebutuhan kualitas nutrisi dan strategi pemberian pakannya.

Tujuan penelitian ini adalah untuk mengetahui karakteristik enzim digesti, terutama protease dan amilase, pada tiga segmen usus, tiga $\mathrm{pH}$ aktivitas dan tiga ukuran ikan berbeda sebagai dasar untuk penentuan kebutuhan kualitas pakan.

\section{Materi dan Metode}

Materi yang digunakan adalah ikan gurami pada fase pertumbuhan yaitu pada ukuran berat 13,29, 35,86 dan 91,86 gram/ekor. Ikan uji diambil dari kelompok petani ikan di wilayah Kecamatan Sumbang, Kabupaten Banyumas. Ikan uji yang diperoleh selanjutnya dibedah untuk diambil saluran digestinya. Selain ikan uji, untuk keperluan penelitian ini juga diperlukan bahan-bahan seperti akuadest, es balok dan reagen kimia untuk analisis enzim digesti. Peralatan yang digunakan untuk keperluan penelitian ini meliputi akuarium fiber, aerator, homogenizer elektrik, spektrofotometer, sentrifuge suhu dingin, freezer, alat bedah dan timbangan analitik. Penelitian dilakukan di laboratorium Fisiologi Hewan Fakultas Biologi Unsoed dan Laboratorium Riset Unsoed, Purwokerto.

Saluran digesti yang diperoleh lalu dipartisi menjadi tiga yaitu segmen usus depan (foregut), tengah (midgut) dan belakang (hindgut) (Gambar 1). Masingmasing segmen usus tersebut selanjutnya diukur aktivitas enzimnya pada $\mathrm{pH}$ asam (23 ), $\mathrm{pH}$ netral (6-7) dan $\mathrm{pH}$ basa (8-9) untuk aktivitas protease, namun untuk aktivitas amilase hanya diukur pada $\mathrm{pH}$ netral.

Untuk keperluan pengukuran aktivitas enzim digesti, saluran digesti ikan yang telah diisolasi, terlebih dahulu dihancurkan menggunakan homogeniser listrik dalam $0,05 \mathrm{M}$ Tris $\mathrm{HCl}(\mathrm{pH} 6-7)$ dingin dengan rasio $1: 2$. Homogenat yang diperoleh kemudian disentrifugasi menggunakan sentrifuse bersuhu $4{ }^{\circ} \mathrm{C}$ pada kecepatan $10.000 \mathrm{rpm}$ selama 10 menit, dan supernatan yang diperoleh siap digunakan untuk uji aktivitas enzim (Natalia et al., 2004). Kadar protein supernatan ditentukan dengan metode Lowry ( Furne et al., 2005), menggunakan albumin sebagai standar. 


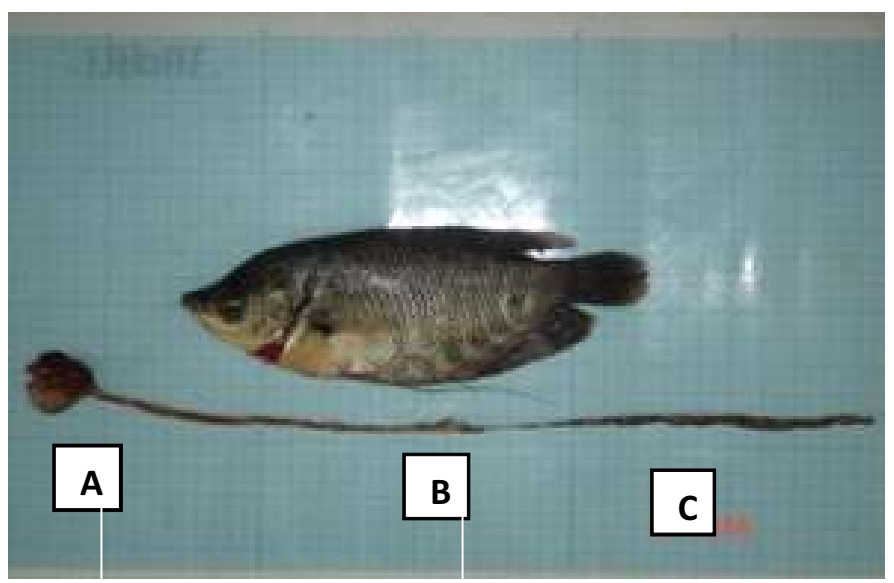

Gambar 1. Ikan gurami yang digunakan dalam penelitian dengan usus yang dipartisi menjadi tiga bagian. A. Usus depan ; B. Usus tengah ; C. Usus belakang

Aktivitas protease diukur menggunakan metode hidrolisis kasein (metode Walter, 1984 dalam Hidalgo et al., 1999). Uji dilakukan menggunakan buffer $0,1 \mathrm{M}$ Glisin- $\mathrm{HCl}(\mathrm{pH} 2-3), 0,1 \mathrm{M}$ tris- $\mathrm{HCl}(\mathrm{pH}$ 6-7) dan 0,05 M Na2HPO4 (pH 8-9) pada $25^{\circ}$ C. Reaksi enzim dimulai dengan mencampurkan $1 \%(\mathrm{w} / \mathrm{v})$ kasein dalam air $(0,5 \mathrm{ml})$, buffer $(0,50 \mathrm{ml})$ dan sampel enzim $(0,25 \mathrm{ml})$ dan diinkubasi selama 60 menit pada $37^{\circ} \mathrm{C}$. Reaksi dihentikan dengan penambahan $0,75 \mathrm{ml}$ dari $8 \%(\mathrm{w} / \mathrm{v})$ asam trichloroacetat (TCA). Setelah diendapkan dalam refrigerator selama 60 menit, campuran reaksi disentrifugasi pada kecepatan 6.000 rpm selama 15 menit. Absorbansi dicatat pada panjang gelombang $280 \mathrm{~nm}$. Tirosine digunakan sebagai standard dan satu unit aktivitas enzim didefinisikan sebagai jumlah enzim yang diperlukan untuk mengkatalisa pembentukan $1 \mu \mathrm{g}$ tirosine permenit. Untuk kontrol, TCA ditambahkan ke ekstrak sebelum ditambah substrat. Aktivitas protease yang terukur sebagai jumlah tirosin yang dihasilkan permenit ditentukan menggunakan kurva kalibrasi tirosin

Aktivitas amilase ditentukan dengan metode hidrolisis pati (Robyt and Whelan, 1968 dalam Hidalgo et al., 1999). Substrat pati disiapkan sebagai $1 \%(\mathrm{w} / \mathrm{v})$ larutan pati (dalam $10 \mathrm{mM}$ phosphate buffer berisi 6,0 $\mathrm{mM} \mathrm{NaCl}$ ). Pada substrat amilum sebanyak $0,75 \mathrm{ml}$ ditambahkan $0,25 \mathrm{ml}$ ekstrak enzim. Campuran reaksi diinkubasi selama 30 menit pada $37^{\circ} \mathrm{C}$ dan $27^{\circ} \mathrm{C}$. Setelah inkubasi tambahkan Iarutan $2 \%$ (w/v) 3,5dinitrosalicylic acid (DNS) segera homogenkan. Campuran reaksi kemudian dimasukkan kedalam air mendidih selama 5 menit. Setelah dingin tambahkan akuades sebanyak $1,5 \mathrm{ml}$. Absorbansi dicacat pada panjang gelombang $540 \mathrm{~nm}$. Jumlah maltosa yang dilepas dari uji ini ditentukan dari kurva standard. Aktivitas amilase dikalkulasi dari rasio antara jumlah maltosa yang dilepaskan $(\mu \mathrm{mol})$ dengan bobot enzim (mg) dalam reaksi campuran kali lama inkubasi (Hidalgo et al., 1999).

Data aktivitas enzim digesti, protease dan amilase, dianalisa dengan menggunakan univariate analysis of variance (Steel dan Torrie, 1981).

\section{Hasil dan Pembahasan}

\section{Aktivitas Protease Digesti Ikan Gurami}

Aktivitas protease digesti pada ikan gurami dengan rerata berat tubuh $13,29 \mathrm{~g}$ tertera pada gambar 2.a. Pada gambar 2.a terlihat bahwa aktivitas protease berkisar antara 2,629 U/mg protein pada hindgut dengan buffer Na2HPO4 dan 6,416 U/mg protein pada midgut dengan buffer Tris- $\mathrm{HCl}$. Hasil analisis varian menunjukkan adanya perbedaaan yang signifikan diantara aktivitas protese pada segmen usus dan buffer berbeda $(P<.05)$. Jadi tampaknya pada ikan gurami ukuran berat rerata $13,29 \mathrm{~g}$ aktivitas protease terjadi di sepanjang usus, namun pada usus belakang aktivitas protease lebih rendah dibandingkan aktivitas protease pada usus depan dan tengah. Pada ikan ukuran rerata berat 13,29 $\mathrm{g}$ ini aktivitas protease dijumpai tinggi pada usus tengah dan usus depan dengan buffer dalam suasana netral, dan umumnya 
aktivitas protease rendah pada suasana basa dengan $\mathrm{pH} 8-9$ (Gambar 2.a).

Aktivitas protease digesti pada ikan gurami dengan rerata berat tubuh 35,86 g/ekor tertera pada gambar 5.1.c. Pada gambar 2.b. terlihat bahwa aktivitas protease berkisar antara $2,579 \mathrm{U} / \mathrm{mg}$ protein pada hindgut dengan buffer Na2HPO4 dan $6,222 \mathrm{U} / \mathrm{mg}$ protein pada hindgut dengan buffer Tris- $\mathrm{HCl}$. Hasil analisis varian menunjukkan adanya perbedaaan yang signifikan diantara aktivitas protease pada buffer berbeda $(P<.05)$, tidak terdapat perbedaan aktivitas protease diantara segmen usus berbeda $(P>.05)$. Jadi tampaknya pada ikan gurami ukuran berat rerata 35,86 g/ekor aktivitas protease juga terjadi di sepanjang usus. Pada ikan ukuran rerata berat 35,86 g/ekor ini aktivitas protease dijumpai tinggi pada usus depan dan usus belakang dengan buffer dalam suasana asam hingga netral, dan umumnya aktivitas protease rendah pada suasana basa dengan $\mathrm{pH} 8-9$ terutama pada usus belakang (Gambar 2.b).
Aktivitas protease digesti pada ikan gurami dengan rerata berat tubuh 91,86 g/ekor tertera pada gambar 2.c. Pada gambar 2.c, terlihat bahwa aktivitas protease berkisar antara $1,585 \mathrm{U} / \mathrm{mg}$ protein pada hindgut dengan buffer Na2HPO4 dan 4,824 $\mathrm{U} / \mathrm{mg}$ protein pada foregut dengan buffer Tris- $\mathrm{HCl}$. Hasil analisis varian menunjukkan adanya perbedaaan yang signifikan diantara aktivitas protease pada segmen usus dan buffer berbeda $(P<.05)$. Jadi tampaknya pada ikan gurami ukuran berat rerata 91,86 g/ekor aktivitas protease juga terjadi di sepanjang usus, namun pada usus tengah dan belakang aktivitas protease lebih rendah dibadingkan aktivitas protease pada usus depan. Pada ikan ukuran rerata berat 91,86 g/ekor ini aktivitas protease dijumpai tinggi pada usus depan dengan buffer dalam suasana asam hingga netral, dan umumnya aktivitas protease rendah pada suasana basa dengan $\mathrm{pH} 8$ - 9 terutama pada usus tengah dan belakang (Gambar 2.c).
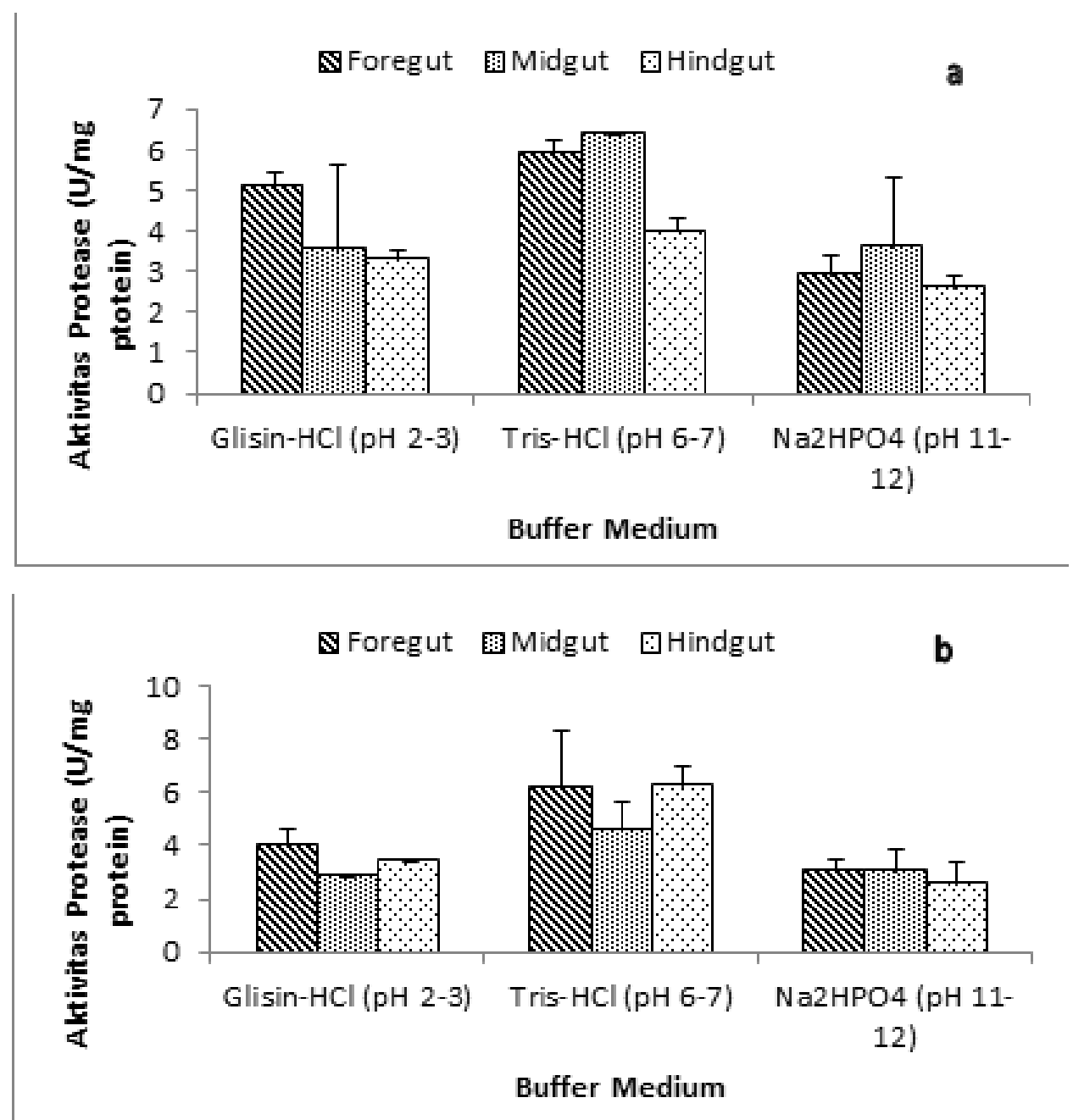


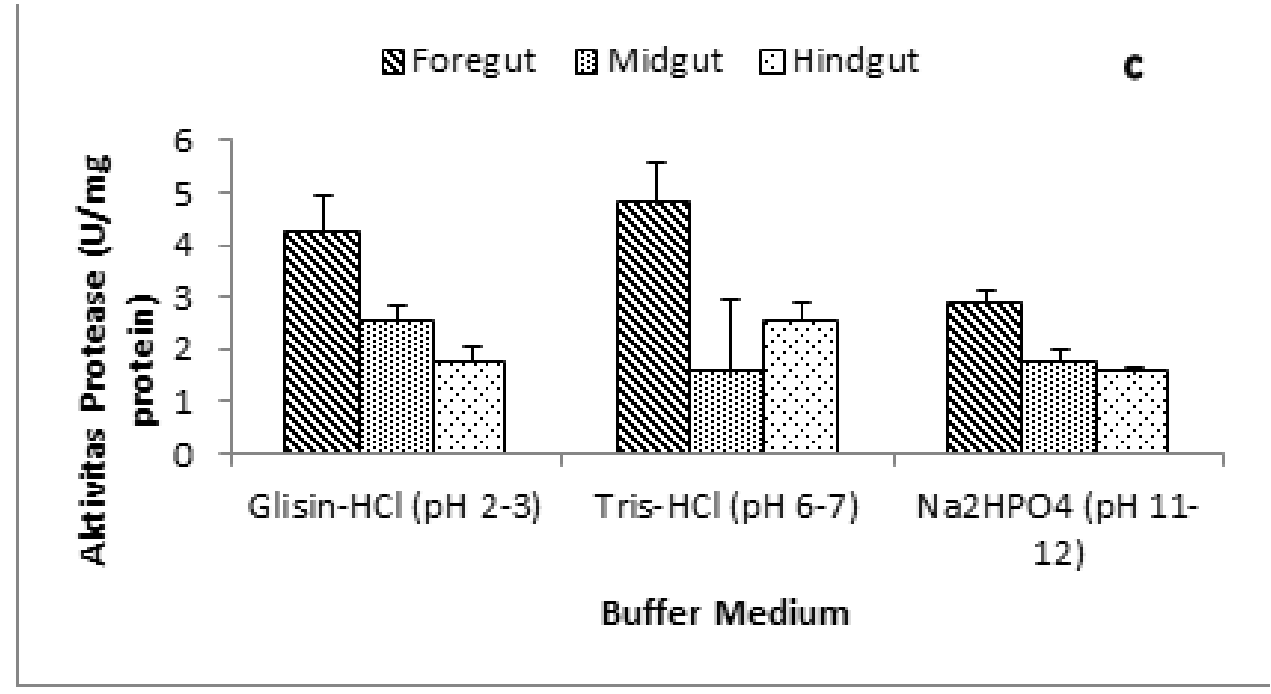

Gambar 2. Aktivitas protease ikan gurami pada tiga segmen usus dan tiga $\mathrm{pH}$ inkubasi pada rerata berat tubuh 13,29 g (a); 35,86 g (b); dan 91,86 g (c).

Fenomena adanya aktivitas protease di sepanjang saluran digesti dengan aktivitas yang tidak seragam juga dijumpai pada penelitian sebelumnya pada ikan, Sparus aurata (Eroldogan et al., 2008), Oreochromis niloticus (Klahan et al., 2009), Glyptosternum maculatum (Xiong et al., 2009), Pangasianodon gigas (Tongsiri et al., 2010), Boleophthalmus pectinirostris \& Bostrichthys sinensis (Renxie et al., 2010). Hasil penelitian ini juga lebih tinggi dari penelitian sebelumnya pada ikan carp, goldfish, seabream (Hidalgo et al., 1999), Catla catla, labeo rohita dan hypophthalmichthys molitrix (Kumar et al., 2007) dan Scleropages formosus (Natalia et al., 2004), namun lebih rendah dari hasil penelitian pada ikan trout, Oncorhynchus mykiss (Furne et al., 2005), Oreochromis niloticus (Klahan et al., 2009),

Pada penelitian ini aktivitas protease lebih tinggi pada usus depan untuk ikan berukuran $13,29 \mathrm{~g}$, namun pola ini berubah pada ikan ukuran yang lebih besar yaitu ukuran $35,86 \mathrm{~g}$ dan $91,86 \mathrm{~g}$. Pada ikan ukuran $35,86 \mathrm{~g}$ aktivitas protease tinggi baik pada usus depan maupun usus tengah terutama pada inkubasi enzim pada suasana netral. Kondisi sebaliknya terjadi pada ikan ukuran besar yaitu aktivitas protease rendah pada inkubasi pH 8-9. Rendahnya aktivitas protease yang dijumpai pada suasana $\mathrm{pH}$ 89 , diduga berhubungan dengan kebutuhan $\mathrm{pH}$ yang optimal untuk protease. Pada penelitian sebelumnya aktivitas protease alkalin perlu suasana alkalis

$\mathrm{pH} 10$ dengan temperatur $45^{\circ} \mathrm{C}$ untuk ikan Sardinops sagax caerulea (CastilloYanez et al., 2004), perlu pH 9-12 untuk ikan Oreochromis niloticus (Klahan et al., 2009), dan perlu $\mathrm{pH}$ 8-10 dan temperatur optimal $55^{\circ} \mathrm{C}$ untuk ikan Zosterisessor ophiocephalus, Raja clavata \& Scorpaena scrofa (Nasri et al., 2011).

Hasil perhitungan aktivitas protease total terendah $(2,08 \mathrm{U} / \mathrm{mg}$ protein) pada ikan dengan berat 91,86 $\mathrm{g}$ dan $\mathrm{pH}$ inkubasi 8-9, sedangkan aktivitas protease tertinggi $(5,44$ $\mathrm{U} / \mathrm{mg}$ protein) diperoleh pada ikan dengan berat tubuh 13,29 $\mathrm{g}$ dan $\mathrm{pH}$ inkubasi 6-7 (Gambar 3). Hasil analisis ragam juga memperlihatkan adanya perbedaan yang siginifikan baik antara $\mathrm{pH}$ inkubasi maupun berat ikan $(P<.0,5)$. Jadi dapat disimpulkan bahwa aktivitas protease pada ikan ukuran $91,86 \mathrm{~g}$ lebih rendah dari pada ikan ukuran yang lebih kecil, demikian juga aktivitas protease lebih tinggi dijumpai pada pH 6-7. 


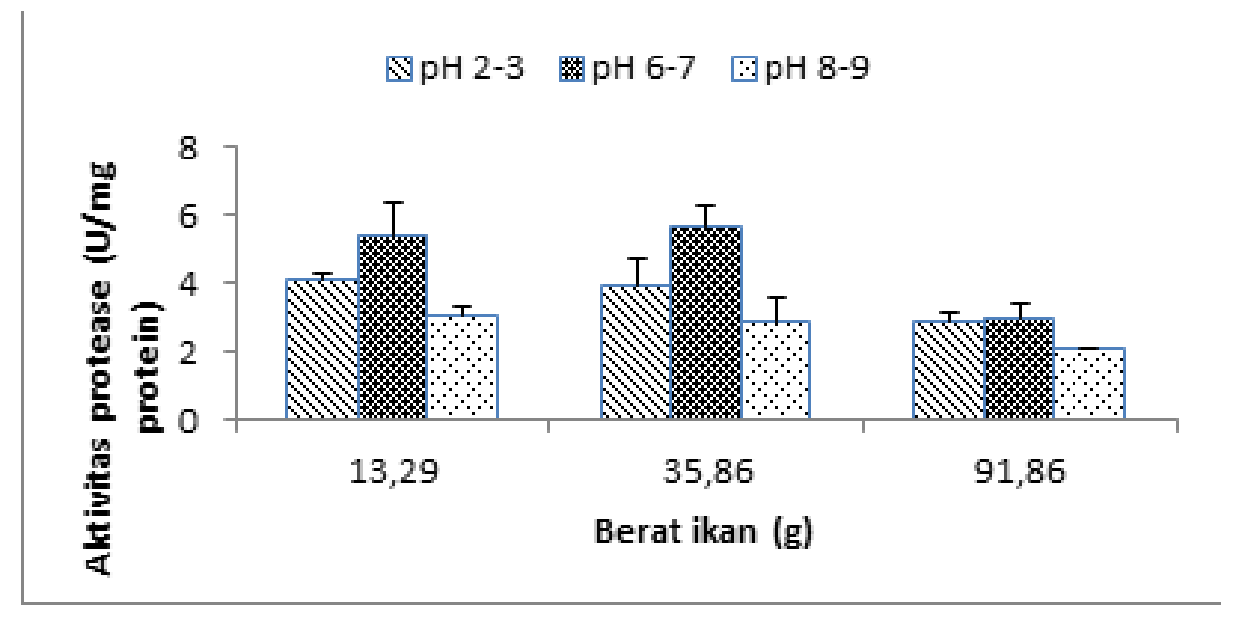

Gambar 3. Aktivitas protease total ikan gurami dengan berat tubuh berbeda

Aktivitas protease yang lebih tinggi pada ikan berukuran kecil dan pada kondisi inkubasi pH 6-7, mencerminkan tingginya aktivitas digesti protein pada ikan yang lebih kecil dibandingkan ikan ukuran yang lebih besar. Hasil penelitian ini dapat menjadi bahan pertimbangan dalam penyusunan formula pakan untuk ikan gurami. Ikan gurami yang berukuran kecil diduga memiliki kebutuhan dan kemampuan digesti protein yang lebih tinggi dari pada ikan yang berukuran lebih besar. Namun, pola ini berbeda dengan yang ditemukan pada ikan Oreochromis niloticus, yang memiliki aktivitas lebih tinggi pada ikan ukuran sedang dibandingkan ikan yang berukuran lebih kecil atau lebih besar (Klahan et al., 2009), demikian juga yang ditemukan pada ikan herbivora, Hyporhamphus regularis ardelio. Pada ikan ini tidak dijumpai perbedaan aktivitas protease antara ikan berukuran kecil dan besar (Day et al., 2011).

\section{Aktivitas Amilase Digesti Ikan Gurami}

Aktivitas amilase digesti ikan gurami yang diukur pada segmen usus dan berat tubuh berbeda serta diukur pada $\mathrm{pH}$ 7-8, hasilnya tertera pada gambar 4 . Aktivitas amilase digesti pada usus depan berkisar antara $0,254 \mathrm{U} / \mathrm{mg}$ protein hingga 0,987 $\mathrm{U} / \mathrm{mg}$ protein, pada usus tengah berkisar antara $0,392 \mathrm{mmol} / \mathrm{mg} / \mathrm{mnt}$ hingga 0,616 $\mathrm{U} / \mathrm{mg}$ protein, sedangkan pada usus belakang berkisar antara $0,431 \mathrm{U} / \mathrm{mg}$ protein hingga $0,511 \mathrm{U} / \mathrm{mg}$ protein (Gambar 4). Hasil analisis sidik ragam menunjukkan bahwa tidak terdapat perbedaan yang signifikan aktivitas amilase digesti ikan gurami diantara segmen usus yang diukur $(P>.05)$, namun terdapat perbedaan yang signifikan aktivitas amilase digesti diantara berat tubuh ikan yang berbeda $(P<.05)$. Tampaknya aktivitas amilase digesti ikan gurami tertinggi dijumpai pada daerah usus depan pada ikan dengan berat rata-rata 13,29 g/ekor (Gambar 3), sedangkan pada usus tengah dan belakang tampak aktivitas amilase digesti dijumpai tidak berbeda, yang menunjukan bahwa pada semua ukuran ikan aktivitas amilase pada usus tengah dan belakang adalah hampir sama. Rata-rata hasil pengukuran aktivitas amilase pada penelitian ini lebih rendah dari yang diperoleh Hidalgo et al. (1999) pada ikan carp, goldfish dan tench, namun lebih tinggi dari pada yang diperoleh pada ikan nila Tilapia (Klahan, et al., 2009), tidak berbeda dengan hasil penelitian Al-Tameemi et al. (2010) pada spesies Cyprinid. Perbedaan asupan nutrisi yang diperoleh ikan nampaknya merupakan salah satu faktor penyebab perbedaan hasil penelitian ini dengan penelitian sebelumnya. Pada penelitian ini, ikan gurami diambil langsung dari pemelihara, sehingga tidak diketahui secara pasti konsumsi pakan harian ikan gurami. Namun, demikian hasil penelitian ini mengindikasikan bahwa ikan gurami memiliki kemampuan untuk mencerna karbohidrat dalam bentuk amilum yang tidak lebih baik dibandingkan ikan Adriatic sturgeon, Acipencer naccarii dan rainbow trout, Oncorhynchus mykiss (Furne et al., 2005), Mekong Giant Catfish, Pangasianodon gigas (Tongsiri et al, 2010), ikan herbivora Hyporhamphus regularis ardello (Day et al., 2011). Hasil penelitian ini 
juga menginformasikan, bahwa untuk mendukung pertumbuhan optimal ikan gurami maka asupan pakan yang diberikan seyogyanya tidak mengandung karbohidrat yang tinggi, karena kemampuannya yang terbatas dalam mendigesti karbohidrat. Namun, demikian berapa kebutuhan optimal karbohidrat perlu kajian lebih lanjut.

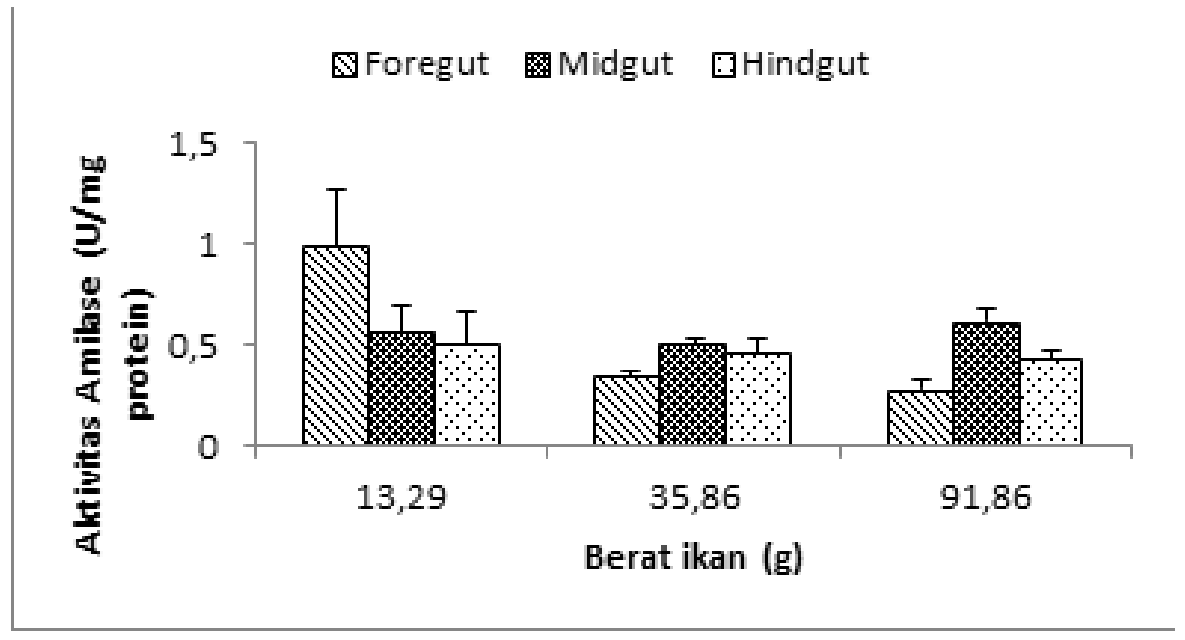

Gambar 4. Aktivitas amilase ikan gurami pada berbagai rerata berat tubuh.

\section{Simpulan}

Aktivitas protease digesti ikan gurami dijumpai sepanjang saluran digestinya baik pada ikan yang berukuran kecil maupun besar. Aktivitas protease umumnya tinggi pada suasana asam dan netral pada usus depan dan tengah. Aktivitas protease ikan yang berukuran besar umumnya lebih rendah dari pada ikan yang berukuran lebih kecil. Aktivitas amilase juga dijumpai pada semua segmen usus yang diuji, dan tidak terdapat perbedaan aktivitas amilase diantara segmen usus yang diuji, namun aktivitas amilase tertinggi dijumpai pada ikan dengan berat rata-rata terkecil.

\section{Ucapan Terimakasih}

Ucapan terimakasih penulis sampaikan kepada Universitas Jenderal Soedirman, Purwokerto yang telah memberikan dana penelitian melalui pendanaan kompetisi Riset Institusional tahun 2011dengan nomer kontrak 1947.08/H23.9/PN/2011 tanggal 18 April 2012.

\section{Daftar Pustaka}

Al-Tameemi, R., Aldubaikul, A., and N.A. Salman, 2010. Comparative study of $\alpha$ - amylase activity in three Cyprinid species of different feeding habits from Southern Iraq. Turkish Journal of Fisheries and Aquatic Sciences. 10 : 411-414.

Castillo-Yanez, F.J., R. Pacheco-Aguilar, F.L. Gracia-Carreno, M.A.N. Toro, 2004. Characterization of acidic proteolytic enzymes from monterey sardine (Sardinops sagax caerulea) Viscera. Food Chemistry. 85: 343-350.

Chan, C-R., D-N. Lee, Y-H. Cheng, D.J-Y. Hsieh and C-F. Weng, 2008. Feed Deprivation and Re-feeding on Alterations of Proteases in Tilapia, Oreochromis mossambicus. Zoological Studies, 47 (2): $207-214$.

Day, R.D., D.P. German, J.M. Manjakasy, I. Farr, M.J. Hansen \& I.R. Tibbetts, 2011. Enzymatic digestion in stomachless fishes : how a simple gut accomodates both herbivory and carnivory. J. Comp. hysiol. B. 181: 603-613.

Eroldoğan, O.T., C. Suzer, O. Taşbozan, and S. Tabakoğlu, 2008. The Effects of Rate-restricted Feeding Regimes in Cycles on Digestive Enzymes of Gilthead Sea-bream, Sparus aurata. Turkish Journal of Fisheries and Aquatic Sciences. 8: 49-54.

Furne, M.C. Hidalgo, A. Lo'pez, M. Garci'aGallego, A.E. Morales, A. Domezain, J. Domezaine', A. Sanz, 2005. 
Digestive Enzyme Activities in Adriatic Sturgeon Acipenser naccarii and Rainbow Trout Oncorhynchus mykiss. A Comparative Study, Aquaculture. 250: 391-398

Hariyadi, B., E. Yuwono, U. Susilo, F.N. Rachmawati dan Y. Sistina. 2010. Pertumbuhan kompensatori dan efisiensi pakan pada ikan gurami, Osphronemus gouramy Lac. Yang mengalami pembatasan pakan secara periodic. Laporan Penelitian Fakultas Biologi, Unsoed, Purwokerto.

Hidalgo, M.C., E. Urea, and A. Sanz, 1999. Comparative Study of Digestive Enzymes in Fish with Different Nutritional Habits. Proteolytic and Amylase Activities. Aquaculture. 170 : $267-283$.

Klahan, R., N. Areechon, R. Yoonpundh and A. Engkagul, 2009. Characterization and Activity of Digestive Enzymes in Different Sizes of Nile Tilapia (Oreochromis niloticus L.). Kasetsart J. (Nat. Sci.) $43: 143-153$

Kumar, S., F.L. Gracia-Carreno, R. Chakrabarti, M.A.N. Toro and J.H. Cordova-Murueta, 2007. Digestive Protease of Three Carps Catla catla, Labeo rohita and Hypophthalmichthys molitrix : Partial Characterization and Protein hydrolysis Efficiency. Aquaculture Nutrition. 13: 381-388.

Nasri, R., I. Younes, I. Lassoued, S. Ghorbel, O. Ghorbel-Bellaaj and M. Nasri, 2011. Digestive alkaline proteases from Zosterisessor ophiocephalus, Raja clavata and Scorpaena scrofa: Characteristics and aplication in chitin extraction. Research Journal of AmonoAcids. doi:10.406/2011/ 913616.

Natalia, Y., R. Hashim, A. Ali, dan A. Chong, 2004. Characterization of Digestive Enzymes in a Carnivorous Ornamental Fish, the Asia Bony Tongoe, Scleropages formosus (Osteoglossidae). Aquaculture. 233 : 305-320.

Odedeyi, D.O., 2007. Digestive Enzymes in the Gut of Snakehead Fish, Parachanna obscura (Gunter, 1861) (Chanidae) in River Ose South Western Nigeria. Journal of Fisheries International. 2(2): 178-181.
Renxie, W., H. Wanshu and Z. Qiyong, 2010. Digestive enzyme activities in mudskipper boleophthalmus pectinirostris and chinese black sleeper Bostrichthys sinensis. Chinese Journal of Oceanology and Limnology. 28(4): 756-761. Journal of The World Aquaculture Society. 36(4): 437-443.

Soedibya, P.H.T., U. Susilo, dan P. Brahmana. 2002. Suplementasi Minyak Ikan Lemuru Pada Pakan Buatan dan Efeknya Terhadap Komposisi Tubuh Serta Retensi Energi Ikan Gurami, Osphronemus gouramy Lac. Sains Akuatik, Vol.5 (2) :50-54.

Soedibya, P.T.H., U. Susilo dan S. Rukayah, 2002. Evaluasi penggunaan tepung kedelai sebagai sumber protein pada pakan berkadar protein berbeda yang disuplementasi minyak lemuru untuk ikan gurami. Laporan Penelitian Fakultas, Unsoed, Purwokerto.

Steel, R.G.D. and J.H. Torrie, 1981. Principles and Procedures of Statistic a Biometrical Approach2 nd. Mc Graw Hill Book Company, Singapore.

Susilo, U., B, Hariyadi dan F.N. Rachmawati. 2000. Pertumbuhan dan Efisiensi Protein Ikan Gurami, Osphronemus gouramy Lac., yang Diberi Pakan Pelet dengan Bahan Baku Lokal. Saint Akuatik. Vol. 3 (1) : $20-27$.

Susilo, U., F.N. Rachmawati dan S. Sukmaningrum, 2003. Efek perbedaan level pemberian pakan terhadap laju konsumsi pakan, pertumbuhan, pemeliharaan tubuh dan efisiensi konversi pakan ikan gurami, Osphronemus gouramy Lac. Laporan Penelitian Fakultas, Unsoed, Purwokerto.

Susilo, U., F.N. Rachmawati dan N. Setyaningrum, 2010. Aktivitas Enzim Digesti Belut Sawah, Monopterus albus Zuiew, dan Ikan Brek, Puntius orphoides C.V., serta Responnya Terhadap Stres Nutrisi. Laporan Penelitian Fakultas, Unsoed, Purwokerto.

Tengjaroenkul, B., B.J. Smith, T. Caceci and S.A. Smith, 2000. Distribution of Intestinal Enzyme Activities Along the Intestinal Tract of Cultured Nile 
Tilapia, Oreochromis niloticus L., Aquaculture. 182:317-327.

Tongsiri, S., K. Mang-Amphan and Y. P e eraporn pisal, 2010. Characterization of amylase, cellulase and proteinase enzyme in stomach and intestin of the mekong giant catfish fed with various diets consisting of Spirulina. Current Research Journal of Biological Sciences. 2(4): 268-274.

Xiong, D.M., C.X. Xie, H.J. Zhang and H.P. Liu, 2009. Digestive enzymes along digestive tract of a carnivorous fish Glyptosternum maculatum (Sisoridae, Siluriformes). Journal of Animal Physiology and Animal Nutrition. 95: 56-64.
Yuwono, E., P. Sukardi dan U. Susilo, 2008. Kondisi Fisiologis Pada Pertumbuhan Kompensatori yang Diinduksi Dengan Pembatasan Pakan Sebagai Upaya Optimasi Produksi Ikan Gurami. Tahun I. Laporan Penelitian Fakultas, Unsoed, Purwokerto.

Yuwono, E., P. Sukardi dan U. Susilo, 2009. Kondisi Fisiologis Pada Pertumbuhan Kompensatori yang Diinduksi Dengan Pembatasan Pakan Sebagai Upaya Optimasi Produksi Ikan Gurami. Tahun II. Laporan Penelitian Fakultas, Unsoed, Purwokerto. 